\title{
METODOLOGI TAFSIR AMINA WADUD DALAM MENAFSIRKAN AL-QUR'AN
}

\author{
${ }^{1}$ Dedi Junaedi, ${ }^{2}$ Muhammadong, ${ }^{3}$ Sahliah \\ ${ }^{1}$ IKIP Siliwangi, Indonesia. ${ }^{2}$ Universitas Negeri Makassar, Indonesia. ${ }^{3}$ STIT Al Ihsan, Indonesia \\ Email: 1dedijunaedi585@gmail.com,2muhammadong74@yahoo.com,3jahemerahsahliah@yahoo.com
}

DOI: $10.29313 /$ tjpi.v8i2.5229

Accepted: October 15th, 2019. Approved: November 30th, 2019. Published: November 30th, 2019

\begin{abstract}
The concept of Aminah Wadud in interpreting the Koran is an idea inspired by Fazlur Rahman which has a neo-modernist orientation in order to find a hermeneutic-based theory. The concept of gender is a theory developed by Amina Wadud so that women's equal rights run in a balanced way with men's rights. The main consideration in hermeneutic-based interpretation, Amina Wadud places more emphasis on the aspect of objectivity rather than the aspect of subjectivity so as to facilitate the interpretation of Qur'anic verses. Amina $W$ adud is more inclined to general principles in contextualizing the understanding of the Koran because it can be more easily understood than textualization because the urgency of the Koran was revealed not based on the text of the verse but seeing the conditions that occur in the field by looking at the character of society.
\end{abstract}

Keywords: Methodology; Commentary; Amina Wadud.

\begin{abstract}
Abstrak
Konsep Amina Wadud dalam menafsirkan Al-Qur'an merupakan gagasan yang diinspirasi dari fazlu Rabman yang berhaluan neo modernis dalam rangka menemukan teori berbasis hermenuetika. Konsep gender merupakan teori yang dikembangkan Amina Wadud supaya bak persamaan perempuan berjalan secara berimbang dengan hak laki-laki. Yang menjadi pertimbangan utama dalam interpretasi berbasis hermenuetika, Amina Wadud lebih menekankan pada aspek obyektivitas bukan aspek subyektivitas sehingga memudabkan dalam interpretasi ayat-ayat Al-Qur'an. Amina Wadud lebih cendrung kepada prinsip umum dalam mengkontekstualisasi pemahaman Al-Qur'an karena dapat lebih mudah dipahami dibanding tekstualis karena urgensi diturunkannya Al-Qur'an bukan berdasarkan teks ayat akan tetapi melihat kondisi yang terjadi dilapangan dengan melihat karakter masyarakat.
\end{abstract}

Kata Kunci: Metodologi; Tafsir; Amina Wadud. 


\section{PENDAHULUAN}

Al-Qur'an adalah memberi petunjuk keagamaan kepada manusia tiga hal pokok: akidah, syariah dan akhlak (M. Qurasih Shihab, 2018). Meskipun proses pewahyuan Al-Qur'an adalah secara bertahap, tetapi cakupan maknanya menjangkau keseluruh ruang dan waktu manusia. Karena itu, Al-Qur'an selalu diperhadapakan pada dua hal pokok. Pertama, bagaimana Al-Qur'an selalu aktual dan koheren dengan kebutuhan masyarakatnya. Kedua, bagaimana orisinalitas keberadaan Al-Qur'an tetap terjaga, meski penafsiran atasnya berubah-ubah (U. Shihab, 2014).

Al-Qur'an membutuhkan pembaca dan pembacaan agar ia bisa bersuara dan pesan-pesannya sampai kepada umat. Dialektika dalam pembacaaan Al-Qur'an karenanya menjadi sebuah keniscayaan (Taufiq, 2016). Karena tidak menutup kemungkinan perbedaan metodologis seorang mufasir akan menimbulkan perbedaan dalam penafsirannya, karena tafsir bisa juga hasil upaya manusia sesuai dengan kemampuan dan kecenderungannya, maka tidak dapat dihindari adanya peringkat-peringkat hasil karya penafsiran, baik dari segi kedalaman uraian atau kedangkalannya (M Quraish Shihab, 2013), keluasan atau kesempitannya isi tafsirnya.

Di kalangan Umat Islam masih terdapat kesalah pahaman dalam memahami Al-Qur'an. Ini boleh jadi terkait dengan karakter bahasa Al-Qur'an yang multi-interpretatif atau berpeluang untuk ditafsirkan secara beragam (Junaedi, 2017). Misalnya ajaran Islam mengenai keadilan antara laki-laki dan wanita, menimbulkan kegelisahan di diri Amina Wadud ketika melihat keterpurukan wanita Islam di segala bidang. Ia mulai mencari penyebab dari keterpurukan tersebut dengan melihat kepada sumber ajaran Islam terkait dengan wanita. Ia dapati, bahwa mayoritas penafsiran dan hasil hukum Islam ditulis oleh ulama pria dan seringkali membawa bias pada pandangan mereka ("Peran Wanita (menurut Amina Wadud)," 2007). Menurutnya, budaya patriarki telah memarginalkan kaum wanita, menafikan wanita sebagai khalifah fil ardh, serta menyangkal ajaran keadilan yang diusung oleh Al-Qur'an. Ia tertantang dan berjuang (jihad) untuk melakukan reinterpretasi terhadap masalah tersebut dengan menggunakan metode Hermeneutik.

Kegelisahan ini akhirnya menginspirasikan ditulisnya buku $A l$ Qur an and Woman, kemudian Inside The Jihad Gender, Women's Reform in Islam, karya Amina Wadud yang membuat sebuah reformasi terhadap wanita Islam dan merupakan grand proyek intelektualnya sehingga pemikiran dan perannya mulai diperhitungkan. Secara khusus, kajian ini mengfokuskan pada masalah bagaimana metodologi yang digunakan oleh Amina Wadud dalam menafsirkan Al-Qur'an? Bagaimana pandangan wanita atau gender menurut penafsiran Amina Wadud? Sehingga tujuan penelitian ini dapat mengetahui tahap-tahapan metodelogi yang digunakan Amina Wadud dalam menafsirkan ayat-ayat Al-Qur'an.

Kegunaan Penelitian Penelitian ini diharapkan dapat memberikan manfaat sekaligus dapat menambah khazanah ilmu tafsir yang berupa hasil penelitian di antaranya: dapat memberikan kejelasan dan pemahaman kepada ummat tentang metodologi penafsiran Amina Wadud dalam menafsirkan ayat Al-Qur'an. Memberikan sumbangan pemikiran dan memperkaya wacana metodologis kajian keislaman, khususnya dalam studi Al-Qur`an. Metode Penelitian dalam melakukan penelitian ini, penulis menggunakan 
penelitian kepustakaan (Library research) dengan pendekatan content analisis, terhadap metodologi Amina Wadud dalam menafsirkan ayat-ayat Al-Qur'an. Dalam operasinya penelitian ini lebih ditekankan pada penelaahan dan pengajian terhadap penafsiran Amina Wadud dalam karya tafsirnya, serta literatur-literatur yang ada hubungannya dengan penelitian ini.

Dalam Penelusuran kajian-kajian terdahulu, kiranya belum ada yang ngebahas secara khusus metodologi tafsir Amina Wadud dalam menafsirkan ayatayat Al-Qur'an. Sehingga kajian ini memberikan kontribusi ilmiah tentang masalah tersebut. Beberapa menelitian tentang Amina Wadud sudah banyak terutama dijurnal ilmiah, diantaranya. "Tafsir Ayat-ayat Gender ala Amina Wadud Perspektif Hermeneutika Gadamer." Karya Irsyadunnas; yang cenderung memokuskan menafsirkan ayat-ayat gender (Irsyadunnas, 2015); Amaliatunwalidaini, "Telaah atas Pemikiran Amina Wadud" membahas tentang pemikiran gender dan isu-isu terbadap perempuan". Cahya Edi Setyawan. "Pemikiran Keseteraan Gender dan Feminisme Aminah Wadud Tentang Eksistensi Wanita dalam Kajian Hukum Keluarga", hal yang dibahas yang berkaitan dengan ayat Al-Qur'an tentang proplem keluarga dan status perempuan dalam keluarga (Cahyaningrum, Sudaryanti, \& Purwanto, 2017). Sedangkan kajian artikel ini Memofuskan kepada pada masalah metodologi Amina Wadud dalam menafsirakn ayat-ayat Al-Qur'an, sehingga memiliki fokus berbeda dengan kajian para peneliti yang lain.

\section{HASIL DAN PEMBAHASAN}

\section{Biografi Amina Wadud}

Amina Wadud terlahir dengan nama Maria Teasley. Beliau dilahirkan di Bethesda, Maryland, Amerika pada 25
September 1952. Nama orang tuanya tidak diketahui, namun bapaknya adalah seorang pendeta yang taat. Sedangkan ibunya keturunan dari Muslim para budak Arab, Berber dari Afrika. Amina Wadud dipertimbangankan oleh banyak orang sebagai seorang pemikir Islam dan pejuang hak-hak perempuan (Cik Hasan Bisri, 2010). Beliau mengakui bahwa beliau tidak begitu dekat dengan ayahnya dan ayahnya tidak banyak mempengaruhi pandangannya. Dalam usianya 20 tahun beliau mendapatkan Hidayah. Ketertarikannya terhadap Islam, khususnya dalam masalah konsep keadilan dalam Islam (gender), mengantarkannya untuk mengucapkan dua kalimah syahadah pada hari yang ia namakan "Thanks giving day", tahun 1972. I did not enter Islam with any eyes closed againts structure and personal experiences of injustice that continue to exist. In my "personal transition,"most often called conversion, however, I focused with hope and idealisme to find greater acces to Allah as al-Wadud, the Loving God of Justice (Wadud, 2006) dia melafadkan syahadat dan memeluk Islam (hal ini lebih didasarkan pada pilihannya, bukan karena dari jalur keluarga atau ibunya). Dia memperoleh BS-nya dari University of Pennsylvania, pada tahun 1975. Dia memperoleh gelas MA-nya dalam kajian Near Eastern Studies, di University of Michgan. Pada tahun 1986, dan Ph.D.nya dari Arab Saudi University of Michigan, pada tahun 1989. Dia belajar studi Quran dan tafsir di American University di Kairo, dan mengambil kursus philosophy pada Universitas alAzar, juga belajar bahasa Arab di Universitas al-Azhar Mesir. (Wadud, 2006).

Amina Wadud hidup di Negara yang kurang peduli terhadap agama yaitu Amerika. Selain itu beliau juga menempuh pendidikan Masternya dalam kajian Studi Islam. Kedua hal ini yang mempengaruhi pemahaman atau 
pemikirannya sehingga besifat liberal. Amina wadud menguasai beberapa bahasa seperti Inggris, Arab, Turki, Jerman dan Spansol.

Di masa mudanya, ia mendapatkan gelar kesarjanaan dari University of Pennsylvania yang kemudian ia lanjutkan pada 1988 untuk meraih gelar M.A. di Near Eastern Studies dan Ph.D. di Arabic and Islamic Studies.

Amina Wadud merasa tidak cukup hanya dengan pengetahuanpengetahuan yang telah diperolehnya dari negaranya sendiri. Maka, ia pun beranjak ke negeri pyramid untuk meningkatkan studi tentang keislamannya di American University in Cairo. Ia memperdalam pembelajaran seputar Al-Qur'an dan tafsir di Cairo University. Untuk menyempurnakannya ia mengambil pendidikan kursus tentang kefilsafatan di Al-Azhar University. Telah sempurnalah jenjang pendidikan yang ia lalui yang telah mengantarkannya menjadi seorang professor studi Islam di Departemen Studi Islam dan Filsafat Universitas Commonwealth di Richmond, Virginia.

Dalam beberapa literature, dapat kita ketahui bahwa beliau merupakan seorang yang aktif di berbagai organisasi perempuan di Amerika dan berbagai diskusi tentang perempuan, serta gigih menyuarakan keadilan Islam antara lakilaki dan perempuan pada berbagai diskusi ilmiah di berbagai daerah maupun Negara. Beliau mendirikan organisasi Sister Islam di Malaysia.

Pemikiran Amina Wadud dalam bukunya Al-Qur'an and Woman (Wanita di dalam Al-Qur'an) dipengaruhi oleh pemikiran Fazlur Rahman. Hal ini bisa kita lihat dari metode dan pendekatan yang digunakan dalam menafsirkan ayatayat yang berhubungan dengan jender sama dengan metode yang digunakan oleh Fazlur Rahman.

Dalam bukunya, Inside The Gender Jihad, ia menulis bahwa ia telah menjadi the single parent lebih dari 30 tahun bagi empat orang anaknya. Hal ini, menurutnya, merupakan awal jihadnya dalam memperjuangkan hak-hak keadilan bagi para wanita Islam.

Sebagai seorang tokoh Studi Islam dan Aktivis Jender sudah sewajarnya memiliki karya-karya yang beredar di masyarakat. Ada pun beberapa karya beliau diantaranya: 1. Qur'an and Women (Wanita di dalam Al-Qur'an ); dan 2. Inside The Gender Jihad Women's Reform in Islam.

\section{Konsep Text dan Hermeneutik Menurut Amina Wadud}

Ketika memahami atau interpretasi Al-Qur'an dapat menjadi dua tahap : membaca dan menafsirkan. Pada tingkat "membaca", setiap pembaca menafsirkan tatkala ia membaca. Tahap interptretasi ini dibentuk oleh sikap, pengalaman, daya ingat dan perspektif tentang bahasa dari setiap pembaca: tesk sebelumnya. Pada kebanyakan topik, teks sebelumnya itu mereflesikan persepsi tertentu tentang gender. Perhatian khusus terhadap gender dalam nash tersebut membawa persepsi demikian ke latar depan dan memfokuskan pada persepsi itu dalam hubungan-hubungan tertentu. Pada tingkat penafsiran, dilakakukan upaya untuk mengatasi perspektif individu untuk mendekati Al-Qur'an secara lebih objektif. Penggunaan beberapa keahliah pendukung -ilmu-ilmu Al-Qur'an dan penerapan metodologi penafsiran dimaksudkan untuk menggiring kearah objektivitas. Akan tetapi, tidak ada mufasir yang mampu menghilangkan signifikansi pemahaman pribadi dan kekuatan teks sebelumnya dari proses penafsiran (Mintarsih, n.d.).

Sikap setiap mufasir cenderung membentuk interpretasinya sendiri terhadap ayat-ayat tertentu dan prinsip Al-Qur'an yang umum. Bahwa kebanyakan ahli tafsir disusun oleh laki- 
laki menunjukkan ada sesuatu pada perempuan dan penafsirannya. Barangkali perempuan dapat mensetujui karya-karya tafsir ini, seluruhnya atau sebagian. Barangkali perempuan dapat menolak dan telah menolak, tapi dengan enggan mensetujui "sumber-sumber" ini tanpa protes, atau tidak mampu membuktikan kebeneran penolakan mereka. Apapun alasannya, tidak ada catatan, dalam warisan Islam kita.

Motivasi Amina Wadud dalam pokok pembahasannya dalam memahami Al-Qur'an adalah untuk menentang sebagian sikap dan hasil penafsiran tentang perempuan dan Al-Qur'an. Dengan tegas, dia menetang arogansi kaum laki-laki yang menuntut suatu sikap martabat dan kehormatan manusia bagi diri mereka sendiri seraya menolak hal yang sama untuk manusia lain, dengan alasan apapun-termasuk hanya karena ia adalah seorang perempuan. Secara khusus, Aminah Wadud menolak pembenaran yang salah terhadap arogansi seperti itu karena penafsiran yang sempit atau penafsiran yang salah terhadap ayat Al-Qur'an, yaitu penafsiran yang mengabaikan prisnsip social pokok tentang keadilan, persamaan dan kemanusia (Mintarsih, n.d.).

Tidak ada metode penafsiran AlQur'an yang sepenuhnya objektif. Setiap penafsiran membuat sejumlah pilihan yang sifatnya subjektif. Berbagai rincian penafsiran kadangkala mencerminkan pilihan subjektif para penafsiran, tanpa mementingkan maksud ayat yang hendak ditafsirkan. Bahkan, seringkali tidak dibedakan antara ayat dan penafsiran. Amina Wadud mencoba mengklasifikasikan penfsiran-penafsrian masalah perempuan Al-Qur'an yang selama ini, termasuk dalam tiga kategori yaitu: Tradisonal, reaktif, dan holistic.

Kategori pertama, interpretasi perempuan di dalam Al-Qur'an yang disebut "tradisional" klasik maupun modern, dengan pokok pembahasan tertentu yang dipilih oleh mufassirnya. Pokok pembahasan tersebut bisa saja hukum, tasawuf, nahwu-sharaf, balaghah, maupun sejarah. Meskipun pokok pembahasan ini menyebabkan lahirnya berbagai perbedaan penfsiran, terdapat satu kesamaan pada karya tradisional, yaitu metodologinya yang atomistic. Tafsir itu akan dimulai dengan pembahasan dari ayat pertama pada surat pertama, kemudian beralih pada ayat kedua surat pertama-satu ayat pada satu waktu-hingga ayat terakhir dari AlQur'an. Hampir sedikit, bahkan tidak ada upaya para mufasirnya, untuk mengenal lebih jauh tema-temanya dan membahas hubungan antara ayat-ayat Al-Qur'an secara tematis. Ulasan singkat mengenai kaitan satu ayat dengan ayat lainnya, mungkin ada, tetapi hal ini tampak kurang pas karena tidak disertai dengan penerapan prinsip-prinsip hermeneutik. Metodologi yang menghubungkan hal-hal yang serupa, seperti ide, srtuktur sintaksisi (sharaf), prinsip-prinsip atau kesamaan tema, nyaris tidak ditemukan. (Wadud, 2006).

Tafsir tradisional yang menjadi perhatian adalah bahwa tafsir tersebut ditulis secara eksklusif oleh kaum lakilaki. Hal ini berarti laki-laki dan pengalaman kaum laki-lakilah yang dimaksukkan dalam penafsiran itu. Sementara perempuan dan pengalamannnya ditiadakan, atau visi perspektif, keinginan atau kebutuhan kaum perempuan ditafsirkan menurut pandangan laki-laki.

Kategori kedua, isinya terutama mengenai reaksi para pemikir modern terhadap sejumlah hambatan yang dialami kaum perempuan, baik barbagai individu maupun sebagai anggota masyarakat, yang diangap berasal dari ayat Al-Qur'an. Pada kategori ini, banyak perempuan dan atau orang yang menentang pesan $\mathrm{Al}-$ Qur'an (atau lebih tetap lagi menentang 
Islam) sama sekali. Mereka menggunakan status perempuan yang rendah dalam masyarakat, sebagai pembenaran atas" reaksi“" mereka. Reaksi ini juga gagal mengambarkan perbedaan antara penafsiran dan ayat Al-Qur'an itu sendiri.

Persoalan yang sering dibahas dan metode yang digunakan pada kategori kedua ini, seringkali berasal dari gagasan kaum feminis rasional. Meskipun para penafsirnya, yakni para pemikir modern ini, seringkali menitik beratkan uraian mereka pada masalah-masalah yang absah. Akan tetapi ketiadaan analisis AlQur'an yang komprehensif, kadangkadang menyebabkan mereka mempertahankan dan membenarkan kaum perempuan pada posisi yang sama sekali tidak wajar, dengan alasan hal tersebut sejalan dengan kedudukan perempuan di dalam Al-Qur'an. Pandangan terakhir ini harus direndam, dalam upaya membuat mulusnya langkahlangkah efektif untuk pembebasan kaum perempuan, yakni memperlihatkan hubungan antara pembebasan para perempuan dengan sumber utama ideologi dan teologi Islam, yang tidak lain adalah Al-Qur'an itu sendiri (Wadud, 2006).

Kategori ketiga, adalah interpretasi yang mempertimbangkan kembali seluruh metode penafsiran Al-Qur'an seraya mengaitkannya dengan berbagai persoalan sosial, moral, ekonomi, dan politik modern, termasuk masalah perempuan. Dalam kategori inilah, Aminah wadud meletakkan tentang perempuan dalam kaitannya dengan keseluruhan Al-Qur'an dan prinsip-prissif pokoknya (Wadud, 2006).

Interpretasi yang dimaksud oleh Amin Wadud yang didalamnya terkandung pengalaman kaum perempuan dan tanpa stereotip yang telah dibuat dalam kebanyakan kerangka interpretasi kaum laki-laki. Dalam analisisnya, interetasi ini akan berlawanan dengan sejumlah kesimpulan mengenai masalah perempuan yang ada selama ini. Dia menganalisis ayat-ayat Al-Qur'an dan bukunnya menganalisis tafsir ayat-ayat, perlakuannya terhadap masalah perempuan akan sangat berbeda dengan kebanyakan karya-karya yang ada mengenai topik serupa (Mintarsih, n.d.).

\section{Hermeneutik: Sebuah Model Metodologi}

Hermeneutik pada dasarnya adalah cara untuk menafsirkan simbol yang berupa teks atau sesuatu yang diperlakukan sebagai teks untuk mencari arti dan maknanya. Hermeneutik ini mengisyaratkan adanya kemampuan untuk menafsirkan masa lampau yang tidak dialami, kemudian dibawa kemasa sekarang (Sudarto, 1996).

Dalam melakukan analisis sebuah teks, baik teks Al-Qur'an maupun teks naskah-naskah lainnya, ada beberapa pertanyaan filologis yang perlu diperhatikan, antara lain:
a. Dari mana teks itu diperoleh?
b. Bagaimana autentisitas dan orisinalitas teks itu?
c. Teks aslinya dari bahasa apa?
d. Siapa yang menerjemahkannya?
e. Terjemahan dari bahasa asli atau bahasa lain?
f. Jarak waktu penerjemah dengan teks-teks terjemahan?
g. Atas sponsor siapa teks dan penerjemahkan itu dilakukan?
h. Soal penerjemahan perlu diperhatikkan, karena tranliterasi dan transformasi suatu teks ke dalam redaksi dan bahasa lain sudah tentu akan membawa reduksi. Setiap bahasa mempunyai latar belakang budaya, karena nya bagaiman latar belakang budaya teks itu?

Ada juga yang mengatakan bentuk hermeneutik adalah salah satu 
bentuk metode penafsiran kitab suci, dalam pengoperasiannya untuk memperoleh kesimpulan makna suatu teks (ayat), ada empat langkah yang perlu dilakukan;

a. Menafsirkan menurut arti secara bahasa

b. Menafsirkan dalam menguraikan arti kedua yang dipahami oleh penafsir Al-Qur'an, baik yang ditambah maupun yang diganti dari arti pertama

c. Menafsirkan sebuah teks sebagai arti tambahan dengan pemahaman bahwa sebuah teks juga memiliki arti yang beragam

d. Menafsirkan tidak lagi menurut kebahasaan, tetapi arti yang dibuat untuk teks tersebut melalui perkembagan terhadap teks tersebut.

Sedangkan yang dimaksud dengan bentuk hermeneutik menurut amina Wadud adalah salah satu bentuk metode penafsiran kitab suci, dalam pengoperasianya untuk memperoleh kesimpulan makna suatu teks (ayat). Selalu berhubungan dengan tiga aspek teks itu, yaitu

a. Dalam konteks apa suatu teks ditulis jika dikaitkan dengan AlQur'an, dalam konteks apa ayat itu diwahyukan,

b. Bagaimana komposisi tata bahasa teks (ayat) tersebut (bagaimana pengungkapannya, apa yang dikatakannya,

c. Bagaimana keseluruhan teks (ayat), Weltanschaunngnya, atau pandangan dunianya, seringkali perbedaan pendapat bisa dilacak dari variasi dalam penekanan ketiga aspek ini (Wadud, 2006).

Hermeneutik sebagai inti penafsiran, harus menjadi titik penekanan karena sumber yang satu bisa membawa pada kesimpulan yang berbeda. Amina Wadud melihat, metode penafsiran baik dulu maupun sekarang, kebanyakan tidak memasukkan tentang perempuan dan pengalaman-pengalamannya. Oleh karena itu, penafsiran Quran dan Sunah serta aplikasinya dalam membentuk hukum Islam, pemerintah, kebijakan umum didasarkan pada hak istimewa penafsiran mufasir (laki-laki).

Amina Wadud mencoba menggunkan metode penafsiran $\mathrm{Al}$ Qur'an yang diajukan oleh Fazlur Rahman, berpandangan bahwa Al-Qur'an muncul dalam sinaran sejarah dan berhadapan dengan latar belakang sosiohistoris. Al-Qur'an adalah sebuah respons terhadap situasi yang sebagian besar merupakan pernyataan-pernyataan moral, religius, da sosial yang mengnanggapi berbagai persoalan spesifik dalam situasi konkret, yang berpendapat bahwa semua ayat Al-Qur'an, sebagaimana pada saat ayat-ayat itu diwahyukan pada pada waktu tertentu dalam sejarah, beserta keadaan yang umum maupun yang khusus menyertai menggunkan ungkapan yang relatif mengenai keadaan tersebut. Tetapi pesan Al-Qur'an tidaklah berarti dibatasi oleh waktu atau keadaan yang bersifat historis tersebut. Pembaca atau penafsir harus paham implikasi (yang tersirat) dari penyataan Al-Qur'an, sewaktu pernyataan itu diwahyukan, dalam upaya menetukan makna utamanya. Makna tersebutlah yang menyampaikan maksud peraturan atau prinsif-prinsip pada ayat-ayat tersebut (Safrudin, 2011).

Menurut Rahman, yang penting adalah bagaimana memahami Al-Qur'an dengan metode yang tepat untuk mengungkap kandungan Al-Qur'an, karena dalam kenyataannya, Al-Qur'an itu laksana puncak sebuah gunung es yang terapung, Sembilan persepuluh darinya di bawah lautan sejarah dan hanya sepersepuluh darinya yang tampak di pemukaan. Karena itulah untuk 
memahami Al-Qur'an, orang harus mengetahui sejarah Nabi dan perjuangannya selama kurang labih dua puluh tiga tahun. Selama itu juga perlu memahami setuasi dan kondisi bangsa Arab pada awal Islam serta kebiasaan, pranata-pranata dan pandangan hidup orang Arab (Rahman, 2000).

Al-Qur'an tidak mengalihkan pembacanya dari prinsip-prinsip moral dengan terlalu banyak bercerita tentang individu tertentu. Karena itu, kita perlu menetapan proses penafsiran yang mencari makna dari merujuk kepada tokoh tertentu. Fazlur Rahman berpendapat bahwa "proses penafsiran merupakan gerakan ganda dari situasi sekarang ke masa Al-Qur'an, kemudian kembali kemasa sekarang sebab AlQur'an adalah jawaban Tuhan, melalui pikiran Nabi, terhadap situasi moralsosial jazirah Arab zaman Nabi. AlQur'an dan munculnya komitas Islam terjadi dalam sejarah dan menentang latar belakang social-sejarah. Al-Qur'an adalah respon terhadap situasi yang merespon berbagai persoalan khusus yang dihadapi dalam situasi sejarah kongkrit.

Rahman mengembangkan suatu metode atau teori interpretasi teks AlQur'an sosial-historis yang dikenal dengan teori double movement (gerakan ganda) yang menjelaskan dua konsep, nilai historisitas" dan nilai moral". Teori double movement menjelaskan penafsiran dua arah, yaitu melakukan ziarah pemahaman terhadap lahirnya teks pada masa lampau dengan memahami kondisi saat ini dengn merumuskan visi Al-Qur'an yang utuh dan membawa kembali dalam situasi sekarang (Rahman, 2000). Double Movemen ialah melihat kondisi dan situasi ayat itu diturunkan agar mendapatkan nilai atau pesan moral yang terkandung dalam ayat-ayat tersebut ("Peran Wanita (menurut Amina Wadud)," 2007).
Dalam kerangka ini, maka pemahaman terhadap situasi kesejarahan (konteks yang melatarbelakangi turunnya Al-Qur'an), merupakan suatu keharusan untuk dapat mengungkap makna teks yang sebenarnya. Tanpa memahami konteks kesejarahan tersebut, upaya untuk memahami pesan Al-Qur'an secara komprehensif akan merupakan sebuah pekerjaan yang sia-sia.

Berdasarkan asumsi atau paradigma dasar tersebut, Rahman menyusun kerangka metodologi hermeneutiknya dalam tiga tahap:

a. Mempelajari Al-Qur'an dalam tatanan kronologisnya, pembacaan Al-Qur'an secara kronologis, akan menyelamatkan penafsir dari penafsiranyang bersifat artificial serta dapat menetapkan makna rincian dan makna keseluruhan dari pesan AlQur'an secara sistematis. Pada tahap ini Al-Qur'an harus dipahami dalam bentang karir dan perjuangan Nabi Muhammmad saw.

b. Membedakan antara ideal moral dengan legal spesifik Al-Qur'an

c. Memahami dan menetapkan saran-sasaran Al-Qur'an dengan memperhatikan latar belakang sosiologinya. Dalam aplikasi metodisnya, Rahman menyarankan untuk memperhatikan pandangan dunia Al-Qur'an (ide tentang Tuhan, alam dan manusia) dan merumuskan sistematika etika $\mathrm{Al}$ Qur'an (iman, Islam dan takwa) yang menjadi basiss penafsirannya, khusus nya dalam menetapkan legal spesifik dan ideal moral Al-Qur'an, serta dalam menetapkan sasaran AlQur'an dalam konteks atau penerapannya pada masalah aktual sekarang. 
Amina Wadud, pada awalnya mengungkap penyataan awal mengapa Al-Qur'an secara khusus menyebut lakilaki dan perempuan dalam suatu keadaan tertentu (seperti laki-laki yang beriman, perempuan-perempuan yang beriman (bentuk jamak maskulin/mudzakar) didekati dengan bentuk jama feminim/muanas. Sementara itu, pada keadaan lain, Al-Qur'an justru menggunakan istilah yang netral: "Hai orang-orang yang beriman..."(dalam bentuk jamak mudzakar? menurut pandangan Amina, setiap penggunaan bentuk jamak maskulis dalam Al-Qur'an, ditujukan baik laki-laki maupun permpuan secara setara, atau tidak, kata ini mengandung petunjuk khas, seakan khusu diterapkan untuk kaum laki-laki.

Semua ayat yang mengandung petunjuk kepada perempuan, secara terpisah atau bersama dengan laki-laki, dianalisis dengan metode tradisional tafsir Al-Qur'an bil Al-Qur'an, akan tetapi, Amina Wadud menguraikan makna khusus ini dengan metode sebagai berikut:

a. Dalam konteks apa ayat itu berbicara;

b. Analisis dalam konteks pemahaman topik yang sama di dalam Al-Qur'an;

c. Menyangkut bahasa yang sama dan srtuktur sintaksis yang digunakan dalam Al-Qur'an;

d. Berpegang teguh pad prinsifprinsip dasar Al-Qur'an; dan

e. Dalam konteks Al-Qur'an sebagai worldview atau pandangan hidup (Cik Hasan Bisri, 2010).

\section{Prior Text Bahasa Khusus Gender}

Menurut Amina wadud, salah satu satu unsur untuk menafsirkan dan memahami berbagai teks adalah yang disebut "prior texk (latang belakang, persepsi dan keadaan) individu penafsir, yaitu bahasa dan konteks kultual dimana teks tersebut ditafsirka. Prior texk pada satu sisi menunjukkan berbagai keragaman yang secara alamiah ditemukan di kalangan mufasir, dan pada sisi lain memperhatikan keunikan masingmasing penafsiran.

Prior text-lah yang memperluas perspektif dan kesimpulan penafsiran. Itu pula yang menunjukkan individualis tafsiran. Tidak bias dikatakan apakah tafsir itu baik atau buruk. Namun, tatkala individu penafsir berikut pandangan hidup dan prior text tertentu yang menyertainya mengatakan bahwa interpretasilah satu-satunya yang dapat diterima atau yangdiperolehkan. Sikap demikian akan menghadpi penafsiran lain, yang berbeda situasi, keadaan, waktunya (kondisinya), mencari tafsiran yang sesuai dengan context mereka.

\section{Kata Kunci dan Konsep dalam Al- Qur'an}

Selain menganalisi gender menurut bahasa Arab Al-Qur'an, Amina Wadud memandang perlu kata kunci (weltanschaumn) (Izutsu, 2003) dan ungkapan penting tertentu yang berhubungan dengan manusia pada umum dan perempuan khusunya untuk memahami kontekstual. Kata-kata mempunyai makna dasar yang dapat dipahami melalui makna itu, ketika terpisah sendiri dan makna relasional yang makna konotatifnya berasal dari konteks di mana kata itu digunakan.

Toshihiko izutsu membuat perbedaan teknis antara makna dasar dan makna relasional sebagai salah satu konsep metode utama dalam semantik (Izutsu, 2003). Setiap satu kata mempunyai makna dasar atau konteks konseptual yang tetap. Artinya, meskipun kata tersebut kita terapkan di luar konteks dalam Al-Qur'an, artinya tetap sama. Akan tetapi, konsep itu tidak berdiri sendiri dan terolasi, melaikan terorganisir dalam sistem. Bagian dari diskusi yang 
dilakukan Amnin Wadud adalah untuk membantu mengorganisasikan struktur atau sistem keadilan sosial dalan Islam, khusunya dalam kehidupan dan ptensi kaum perempuan yang memberikan kontribusi relevan dengan komleksitas pluralime global saai ini.

\section{Contoh Penafsiran Ayat Gender Menurut Amina Wadud}

Penciptaan perempuan: ontology tentang diri yang satu

Dalam Al-Qur'an tidak dibedakan secara tegas tentang subtansi kejadian asal-usul kejadian Adam dan Hawa. Memang ada isyarat bahwa Adam diciptakan dari tanah, kemudian dari tulang rusuk Adam diciptakan Hawa, namun isyarat ini diperoleh dari hadits. Kata Hawa yang selama ini dipersepsikan sebagai perempuan yang menjadi istri Adam sama sekali tidak pernah disinggung dalam Al-Qur'an.

Ajaran-ajaran radikal Al-Qur'an, yang membentuk karakteristik kesetaraan gender dalam Islam dan meruntuhkan gagasan perbedaan radikal dan hirarki gender, terkait dengan asal-usul dari karakteristik penciptaan manusia, seperti yang digambarkan Al-Qur'an, meskipun memiliki perbedaan biologis, umat manusia memiliki kedudukan yang sama/serupa secara ontologis dan etismoral dalam pengertian bahwa laki-laki dan perempuan bersumber dari dari yang satu, memiliki sifat-sifat yang sama, dan merupakan pasangan bagi yang lainnya, seperti firman-Nya dalam:

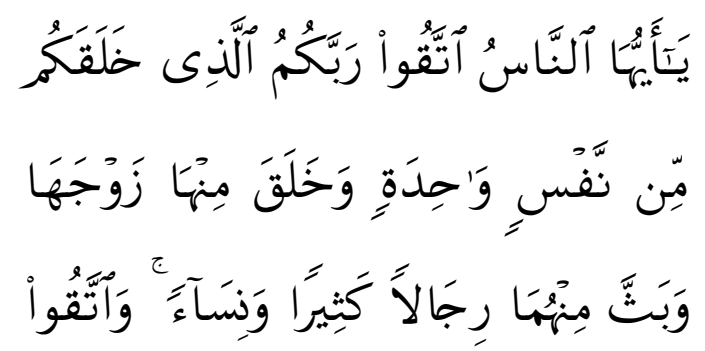

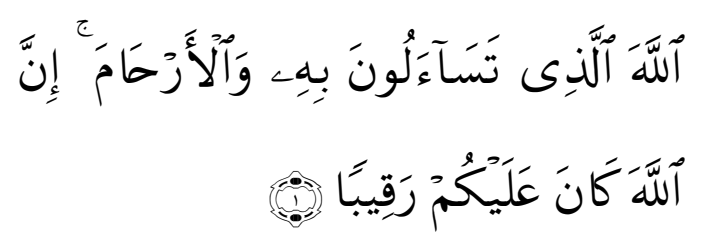

"Hai sekalian manusia, bertakwalah kepada Tuban-mu yang telab menciptakan kamu dari seorang diri, dan dari padanya. Allab menciptakan isterinya; dan dari pada keduanya Allah memperkembang biakkan laki-laki dan perempuan yang banyak. dan bertakwalah kepada Allah yang dengan (mempergunakan) nama-Nya kamu saling meminta satu sama lain, dan (pelibaralah) bubungan silaturrabim. Sesunggubnya Allah selalu menjaga dan mengawasi kamu" (QS. An-Nisa, Ayat 1).

Menurut Amina Wadud, dalam memahami kata nafs pada ayat di atas, kata nafs digunakan secara umum dan teknis. Walaupun kata nafs secara umum diterjemahkan sebagai "diri" dan jamaknya, anfus sebagai "diri-diri ", namun Al-Qur'an tidak pernah pengunakan untuk merujuk pada suatu diri yang diciptakan selain manusia. Dalam Al-Qur'an, nafs merujuk pada asal semua manusia secara umum. Meskipun konsekuensinya manusia berkembang biak di muka bumi dan membentuk berbagai macam negara, namun kita semua mempunyai satu asal yang sama.

Menurut tata bahasa, nafs adalah feminin, anteseden dari kata sifat dan kata kerja feminin yang bersesuaian. Menurutu konsepsi, nafs tidak maskuli maupun feminin, dan menjadi bagian esensial dari setiap orang, laki-laki atau perempuan.

Kata penting lain dalam ayat di atas adalah zanj, sebagaian istilah umum, zawj digunakan dalam Al-Qur'an untuk arti teman, pasangan atau kelompok, dan bentuk jamaknya azwaj, digunakan untuk menunjukkan, pasangan. Ini adalah kata yang digunakan untuk perujuk kepada penciptaan manusia yang kedua, yang kita pahami sebagai hawa, ibu pertama akan tetapi, menurut tata bahasa zawj adalah 
maskulin, anteseden dari kata sifat dan kata kerja maskulis yang bersesuaian. Menurutu konsepsi, kata ini maskuli maupun feminine dan dalam Al-Qur'an digunakan untuk tumbuh-tumbuhan, dan binatang di samping manusia.

Tentang penciptan zawj, lebih sedikit ketimbang tentang penciptaan nafs yang pertama. Al-Qur'an mengatakan hanya ada dua hal tentang penciptaannya yakni min nafs yang pertama dan rawj yang berhubungan dengan nafs itu. (QS.4:1, 7:189, 39:6). Menurutu Amina Wadud, mungkin karena minimnya penjelasan ini yang menyebabkan mufasir Al-Qur'an, seperti al Zamasyari dan ulama lainnya mengadalkan kisah injil yang menyatakan bahwa hawa diciptakan dan (min) tulang rusuk atau pingang Adam (Cik Hasan Bisri, 2010).

Menurut Amina Wadud (Wadud, 2006) bukan bagaimana Hawa diciptakan, tetapi kenyataan bahwa Hawa adalah pasangan dari zawj (Adam). Pasangan menurut Amina, dibuat dari bentuk yang saling melengkapi dari realitas tunggal, dengan sejumlah perbedaan sifat, karakteristik dan fungsi, tetapi kedua bagaian yang selaras ini saling melengkapi sebagaian kebutuahan satu keseluruhan. Setiap anggota pasangan mensyaratkan adanya anggota pasangan lainnya dengan logis dan keduanya berdiri tegak hanya atas dasar hubungan ini. Dengan pengertian seperti itu, penciptaan Hawa dan Adam bagi Amina Wadud merupakan bagian rencana pencitaan Adam, dan dengan demikian keduanya sama pentingnya.

\section{KESIMPULAN}

Amina Wadud adalah seorang pemikir studi Islam. Beliau berusaha bersikaf objektif dalam mengkaji Islam misalnya dalam menafsirkan Al-Qur'an. Selain itu beliau adalah seorang aktivis jender. Yang jelas memberikan tawaran metodologinya dalam membaca AlQur'an dengan mengunakan metode hermeneutik. Amina Wadud mencoba melakukan rekontruksi metodologis bagaimana menafsirkan Al-Qur'an agar dapat menghasilkan sebuah penafsiran yang sensitive gender dan berkeadilan serta pemikiran beliu masih terbuka untuk dikritisi.

\section{DAFTAR PUSTAKA}

Cahyaningrum, E. S., Sudaryanti, S., \& Purwanto, N. A. (2017). PENGEMBANGAN NILAINILAI KARAKTER ANAK USIA DINI MELALUI PEMBIASAAN DAN KETELADANAN. Jurnal Pendidikan Anak, 6(2), 203-213. https://doi.org/10.21831/jpa.v6i 2.17707

Cik Hasan Bisri, D. (2010). Mengerti Qur'an Pencarian bingga Masa Senja 70 thn Prof. Dr. H. A. Chazin Nasuba.

Irsyadunnas, I. (2015). TAFSIR AYATAYAT GENDER ALA AMINA WADUD PERSPEKTIF HERMENEUTIKA

GADAMER. Musãwa Jurnal Studi Gender Dan Islam. https://doi.org/10.14421/musaw a.2015.142.123-142

Izutsu, T. (2003). Relasi Tuban dan Manusia. Yogyakata: Tiara Wacana.

Junaedi, D. (2017). Konsep dan Penerapan Takwil Muhammad Quraish Shihab dalam Tafsir AlMishbah. Wawasan: Jurnal Ilmiah Agama Dan Sosial Budaya. https://doi.org/10.15575/jw.v2i2 .1645

Mintarsih, M. (n.d.). Tesis Pasca UIN SGD Bandung: Metodologi Tafsir Amina Wadud terbadap Ayat-ayat Gender.

Peran Wanita (menurut Amina Wadud). 
(2007). Retrieved from

https://mesw.wordpress.com/20

07/12/31/peran-wanita-

menurut-amina-wadud/

Rahman, F. (2000). Islam dan modernitas: tentang transformasi Intektual. Bandung: Putaka.

Safrudin, A. H. R. \& I. (2011). Dasar-dasar Epistemology Islam. Bandung: Pustaka Setia.

Shihab, M. Qurasih. (2018). Islam yang saya Anut: Dasar-dasar Ajaran Islam. Tangerang: Lentera Hati.

Shihab, M Quraish. (2013). Kaidah Tafsir. Tangerang: Lentera Hati.

Shihab, U. (2014). Kapita Selekta Mozaik Islam. Bandung: Mizan.

Sudarto. (1996). Metodelogi Penelitian Filsafat. Jakarta: Raja Grafindo Persada.

Taufiq, I. (2016). Al-Qur'an Bukan Kitab Teror. Yogyakarta: Bentang.

Wadud, A. (2006). Inside The Gender Jihad Women's Reform in Islam. New York: Oxford University Press. 